\title{
Kebutuhan Sumber Belajar Mahasiswa yang Mendukung Pembelajaran Berbasis Teknologi Informasi dan Komunikasi di Perguruan Tinggi
}

\author{
Imam Fitri Rahmadi ${ }^{1}$ \\ Khaerudin $^{2}$ \\ Cecep Kustandi ${ }^{3}$
}

\begin{abstract}
This study is aimed at gathering information about the tendency of learning resources needed by the students of Universitas Negeri Jakarta (UNJ) that support ICT based learning. The study is conducted using the survey method applying questionnaires that randomly distributed to the students. The questionnaires filled in by 580 students of 22 different study programmes covering six faculties of UNJ. Every faculty tends to have different learning resources. However, videos are the most essential learning resources needed by students. The development of learning resources in higher education must consider the need of learning resources of students of each faculty, not the university as a whole.
\end{abstract}

Keywords: ICT based learning, higher education, learning resources.

\begin{abstract}
Abstrak: Studi ini bertujuan untuk mendapatkan informasi tentang kecenderungan jenis sumber belajar yang dibutuhkan oleh mahasiswa Universitas Negeri Jakarta (UNJ) yang mendukung pembelajaran berbasis TIK. Studi dilakukan dengan metode survei menggunakan angket yang disebarkan secara acak kepada mahasiswa. Angket diisi oleh 580 mahasiswa dari 22 program studi yang mencakup 6 fakultas di UNJ. Setiap fakultas memiliki kecenderungan pilihan jenis sumber belajar yang berbeda. Namun secara keseluruhan video merupakan sumber belajar yang paling dibutuhkan oleh mahasiswa. Pengembangan sumber belajar di perguruan tinggi harus mempertimbangkan kebutuhan sumber belajar mahasiswa pada setiap fakultas, bukan hanya secara keseluruhan pada tingkat universitas.
\end{abstract}

Kata-kata kunci: pembelajaran berbasis TIK, perguruan tinggi, sumber belajar.

\section{PENDAHULUAN}

Perkembangan Teknologi Informasi dan Komunikasi (TIK) di abad 21 telah sampai pada dunia pendidikan dan mengubah proses belajar dan pembelajaran. TIK pada pembelajaran abad 21 dimainkan secara aktif sebagai alat, proses maupun sumber (Partnership for 21 Century Learning, 2007), dengan kata lain, teknologi diintegrasikan dalam setiap proses belajar dan pembelajaran (Kereluik, Mishra, Fahnoe, \& Terry, 2013). Implikasinya, hadirnya TIK telah menjadikan proses pembelajaran di pendidikan dasar dan menengah serta pendidikan tinggi mengarah pada pembelajaran berbasis TIK.

Pembelajaran itu sendiri, merupakan proses interaksi antara peserta didik dengan pendidik dan sumber belajar pada suatu lingkungan belajar (UU No. 20 Tahun 2003 tentang Sistem Pendidikan Nasional Pasal 1 Ayat 20). Mengingat proses pembelajaran telah berubah karena adanya TIK, maka pengertian pembelajaran pun berubah menjadi interaksi antara peserta didik dengan

\footnotetext{
${ }^{1}$ Imam Fitri Rahmadi, Program Studi Pendidikan Pancasila dan Kewarganegaraan Universitas Pamulang, email: imamrahmadi@unpam.ac.id, HP.085642228448

${ }^{2}$ Khaerudin, Program Studi Teknologi Pendidikan S2 PPs UNJ, email: khaerudin@unj.ac.id

${ }^{3}$ Cecep Kustandi, Program Studi Teknologi Pendidikan S1 UNJ, email: cecep_kustandi@unj.ac.id
} 
pendidik dan sumber belajar pada suatu lingkungan belajar yang berbasis TIK. Maka, pembelajaran berbasis TIK, diartikan sebagai upaya menyatukan informasi dan teknologi komunikasi dalam budaya baru pembelajaran yang memanfaatkan perangkat elektronik baik analog maupun digital seperti penggunaan telepon genggam, komputer personal, tablet dan laptop baik berdiri sendiri maupun memanfaatkan koneksi internet.

Khususnya terkait sumber belajar, perkembangan TIK diperkirakan telah mengubah kecenderungan jenis sumber belajar yang dibutuhkan oleh mahasiswa di perguruan tinggi. Secara etimologis, sumber belajar terdiri dari dua kata yaitu sumber dan belajar. Setiap kata tersebut mengandung makna tersendiri. Disiplin ilmu Teknologi Pendidikan mendefinisikan sumber (resource) sebagai "asal yang mendukung terjadinya belajar, termasuk sistem pelayanan, bahan pembelajaran, dan lingkungan" (Seels \& Richey, 1994: 13). Sedangkan belajar (learning) didefiniskan sebagai "perubahan yang relatif permanen dalam pengetahuan, perilaku, atau sikap seseorang karena pengalaman" (Seels \& Richey, 1994: 13). Menggabungkan kedua definisi tersebut, berarti sumber belajar merupakan asal atau sesuatu yang dapat mendukung terjadinya perubahan yang relatif permanen pada pengetahuan, perilaku, atau sikap seseorang karena suatu pengalaman interaksi yang terjadi selama proses belajar, seperti menanggapi, menafsirkan, merespon, dan mengambil pelajaran dari suatu umpan balik.

Secara terminologis, menurut Association for Educational Communication and Technology (AECT), sumber belajar merupakan semua sumber termasuk data, orang, dan benda yang dapat digunakan untuk belajar, secara terpisah maupun terkombinasi, demi tercapainya tujuan pembelajaran (AECT, 1986: 9). Sumber belajar dapat dikembangkan by design atau by utilization (Januszewski, 2001: 54), dengan tujuan untuk "...facilitate learning and improving performace" (Januszewski dan Molenda, 2008: 213). Sedangkan menurut departemen pendidikan wilayah Prince Edward Island, Canada (2008), menyatakan definisi sumber belajar sebagai berikut:

Learning resources will refer to any person(s) or any material (whether acquired or locally produced) with instructional content or function that is used for formal or informal teaching/learning purposes. Learning resources may include, but are not limited to, print and non-print materials; audio, visual, electronic, and digital hardware/software resources; and human resources.

Berdasarkan berbagai definisi di atas, dapat disimpulkan bahwa sumber belajar adalah segala sesuatu yang dapat digunakan untuk memasilitasi belajar guna tercapianya tujuan pembelajaran dan meningkatkan kinerja pemelajar dalam belajar dan pembelajaran. Sumber belajar terdiri dari pesan, orang, bahan, alat, teknik, dan latar, yang dapat digunakan secara terpisah atau terkombinasi, di mana pendayagunaannya dapat dirancang secara khusus atau sekadar dimanfaatkan dari segala sesuatu yang sudah tersedia. Sumber belajar dapat digunakan dalam belajar dan pembelajaran non-formal, informal, maupun formal.

Selain definisi di atas, terdapat terminologi lain untuk mengistilahkan sumber belajar, hal ini terutama untuk sumber belajar digital yang berada 
di Internet. Para ilmuan dalam bidang teknologi pendidikan, sejak tahun 2000-an, mulai memperkenalkan istilah learning objects, sebuah istilah untuk menyebut berbagai sumber belajar digital dengan berkualitas tinggi yang banyak bertebaran di Internet (Recker, Dorward, \& Nelson, 2004). Learning objects lazim didefinisikan sebagai "any digital resource that can be reused to support learning" (Wiley \& Agency for Instructional Technology, 2002) atau "any reusable digital resource that is encapsulated in a lesson or assemblage of lessons grouped in units, modules, courses, and even programes" McGreal (2004).

Sumber belajar memiliki kedudukan dan peran yang vital atas terjadinya proses pembelajaran. Sumber belajar yang lengkap, relevan, dan mutakhir dapat mendorong terwujudnya pembelajaran yang berkualitas di perguruan tinggi. Terlebih mengingat bahwa pada perguruan tinggi menggunakan sistem belajar orang dewasa (andragogy), sehingga mahasiswa secara mandiri dituntut proaktif dalam berinteraksi dengan sumber belajar. Semakin lengkap sumber belajar yang ada akan semakin memudahkan mahasiswa dalam belajar dan mendorong ketercapaian tujuan pembelajaran (Rahmadi, 2017a: 91).

Undang-undang Nomor 12 Tahun 2012 tentang Pendidikan Tinggi Pasal 41 Ayat 1, mengamanatkan bahwa sumber belajar pada lingkungan pendidikan tinggi wajib disediakan, difasilitasi, atau dimiliki oleh perguruan tinggi sesuai dengan program studi yang dikembangkan. Undang-undang tersebut secara tersurat menginstruksikan kepada istitusi perguruan tinggi untuk mengembangkan sumber belajar sesuai dengan kebutuhan. Pengembangannya bersifat wajib, bukan lagi sekadar anjuran atau saran.

Sumber belajar perlu dikembangkan karena; 1) perkembangan yang sangat cepat pada ilmu pegetahuan, teknologi, dan seni; 2) belajaran dan pembelajaran tatap muka memiliki waktu yang terbatas; 3) pemelajar memiliki haya belajar yang beragam; 4) pentingnya pembiasaan belajar mandiri; 5) pemanfaatan secara integratif pada sumber belajar dalam belajar dan pembelajaran; dan 6) adanya inisiatif pengembangan pusat sumber belajar (Sitepu, 2014). Berbagai alasan di atas menunjukkan bahwa sumber belajar harus dikembangkan secara berkelanjutan sesuai dengan perkembangan ilmu pengetahuan, teknologi, dan seni. Selain itu, pengembangaanya juga di dorong atas terbatasnya waktu pembelajaran tatap muka, pembiasaan belajar secara mandiri, dan beragamnya gaya belajar pemelajaran. Hingga pada akhirnya, pengembangan sumber belajar yang masif, untuk dapat melakukan pengelolaan sumber belajar dengan baik, dapat dikembangkan pusat sumber belajar.

Pengembangan sumber belajar dilakukan di atas prinsip memberikan kesempatan seluasluasnya kepada para pemelajar untuk dapat memilih sumber dan cara belajar sesuai dengan gaya belajar. Tujuan pengembangan sumber belajar meliputi; 1) memenuhi kebutuhan sumber belajar dalam belajar dan pembelajaran sesuai dengan gaya belajar pemelajar; 2) memberi kesempatan kepada pemelajar memilih sumber belajar yang sesuai dengan karakteristiknya; 3) melatih kemampuan pemelajar untuk dapat belajar menggunakan berbagai sumber belajar; 4) 
mengatasi masalah belajar secara individual sesuai dengan masalah yang dihadapi masingmasing pemelajar; 5) mendorong pemelajar untuk dapat belajar sepanjang hayat; 6) mendorong terwujudnya model pembelajaran baru yang aktif, inovatif, kreatif, efektif, efisien, dan menyenangkan; serta 7) mengintegrasikan penggunaan sumber belajar dalam belajar dan pembelajaran (Sitepu, 2014). Berbagai tujuan pengembangan sumber belajar yang sudah dikemukaan, menunjukkan bahwa pengembangan sumber belajar memiliki berbagai manfaat praktis dalam belajar dan pembelajaran di dalam maupun di luar kelas.

Pengembangan sumber belajar harus didasarkan pada tujuan pembelajaran, karakter isi materi, karakteristik pemelajar, dan lingkungan belajar dan pembelajaran. Pengembangan sumber belajar yang tidak mempertimbangkan pada aspek tujuan pembelajaran, isi materi, karakteristik pemelajar, dan lingkungan belajar serta pembelajaran dapat mengakibatkan hasil pengambangan sumber kurang sesuai dengan kebutuhan dan konteks yang relevan.

Maka, sebelum melakukan pengembangan sumber belajar di suatu institusi pendidikan, perlu dilakukan terlebih dahulu sebuah studi yang menganalisis kebutuhan sumber belajar yang dibutuhkan oleh pengguna. Atas dasar hal tersebut, Pusat Sumber Belajar (PSB) Lembaga Pengembangan Pendidikan (LPP) Universitas Negeri Jakarta (UNJ), sebagai salah satu Pusat di UNJ yang memiliki fungsi pelayanan dan produksi sumber belajar, melakukan sebuah studi yang menganalisis kebutuhan sumber belajar mahasiswa UNJ.
Studi yang dilakukan difokuskan pada sumber belajar yang mendukung pembelajaran berbasis TIK di perguruan tinggi. Sejauh penelusuran, belum ada studi sejenis yang menganalisis kebutuhan sumber belajar pada suatu institusi secara menyeluruh. Analisis sumber belajar yang pernah dilakukan, berfokus pada salah satu sumber belajar tertentu, seperti analisis kebutuhan modul pembelajaran Ilmu Pengetahuan Alam di Sekolah Dasar (Sari \& Jusar: 2017); analisis kebutuhan worksheet di Sekolah Menengah Kejuruan (Nurhidayah, Zubaidah \& Kuswantoro: 2016); analisis kebutuhan pengembangan perangkat pembelajaran di Sekolah Menengah Atas (Khabibah, dkk: 2015); analisis kebutuhan bahan ajar matematika di Sekolah Menengah Pertama (Priyantoro, Suparman \& Rizki: 2017); dan analisis kebutuhan pengembangan bahan ajar bahasa Jepang di Politeknik (Kanah: 2014).

Sementara para peneliti di luar negeri melakukan analisis eksploratif terhadap kemungkinan media baru yang muncul akibat perkembangan teknologi untuk dapat digunakan sebagai sumber belajar. Eksplorasi dilakukan terhadap kemungkinan computer-mediated communication (McAter, dkk: 1997), social media tools (Liu: 2010), dan facebook (Irwin, dkk: 2012) sebagai sumber belajar. Maka, studi ini dapat memperkaya dan melengkapi hasil studi terdahulu terkait analisis kebutuhan dan eksplorasi media baru sebagai sumber belajar.

Tujuan dari studi ini adalah untuk mendapatkan informasi terkait kecenderungan jenis sumber belajar yang dibutuhkan oleh mahasiswa UNJ yang mendukung pembelajaran berbasis TIK di perguruan tinggi. Secara lebih 
fokus, studi berusaha mendapatkan gambara terkait; 1) kecenderungan jenis sumber belajar yang dibutuhkan oleh mahasiswa pada setiap fakultas; dan (2) kecenderungan jenis sumber belajar dibutuhkan oleh mahasiswa secara keseluruhan pada tingkat universitas. Hasil studi dapat bermanfaat bagi penyediaan dan atau pengembangan sumber belajar di perguruan tinggi yang sesuai dengan kebutuhan pengguna dan perkembangan teknologi.

\section{METODE PENELITIAN}

Studi dilakukan selama empat bulan, mulai bulan Maret - Juni 2017, menggunakan metode survei dengan target populasi mahasiswa UNJ. Pengambilan data dilakukan menggunakan angket yang disebarkan dengan sampel acak (random sampling) kepada mahasiswa dari berbagai tingkat semester. Jumlah mahasiswa yang mengisi survei sebanyak 580 mahasiswa dari 22 program studi yang mencakup 6 fakultas di UNJ. Analisis data dilakukan menggunakan teknik analisis data statistika deskriptif untuk pengambilan kesimpulan dan perumusan rekomendasi. Dalam konteks sumber belajar yang mendukung pembelajaran berbasis TIK, maka jenis sumber belajar yang menjadi pilihan pada survei, meliputi: audio, booklet, brosur, e-book, flipchart, games, jurnal, leaflet, multi media interaction (MMI), mock-up, modul digital, power point (PPt), video, dan web based learning (WBL).

Tabel 1. Fakultas, program studi dan jumlah mahasiswa yang menjadi responden

\begin{tabular}{|c|c|c|c|c|}
\hline No & Fakultas & Program Studi & Responden & Total \\
\hline \multirow{5}{*}{1} & \multirow{5}{*}{ Fakultas Bahasa dan Seni } & Bahasa dan Sastra Inggris & $25(16 \%)$ & \multirow{5}{*}{$158(27 \%)$} \\
\hline & & Pendidikan Bahasa Indonesia & $25(16 \%)$ & \\
\hline & & Pendidikan Bahasa Prancis & $44(28 \%)$ & \\
\hline & & Pendidikan Seni Musik & $38(18 \%)$ & \\
\hline & & Pendidikan Seni Rupa & $36(23 \%)$ & \\
\hline \multirow{2}{*}{2} & \multirow{2}{*}{ Fakultas Ekonomi } & D3 Sekretaris & $32(51 \%)$ & \multirow{2}{*}{$63(11 \%)$} \\
\hline & & Pendidikan Ekonomi & $31(49 \%)$ & \\
\hline 3 & Fakultas Ilmu Olahraga & Pendidikan Olahraga & $38(100 \%)$ & $38(7 \%)$ \\
\hline \multirow{5}{*}{4} & \multirow{5}{*}{ Fakultas Ilmu Pendidikan } & Bimbingan dan Konseling & $38(32 \%)$ & \multirow{5}{*}{$118(20 \%)$} \\
\hline & & Manajemen Pendidikan & $18(15 \%)$ & \\
\hline & & Pendidikan Anak Usia Dini & $19(16 \%)$ & \\
\hline & & Pendidikan Luar Biasa & $8(7 \%)$ & \\
\hline & & Teknologi Pendidikan & $35(30 \%)$ & \\
\hline \multirow{6}{*}{5} & \multirow{6}{*}{$\begin{array}{l}\text { Fakultas Matematika dan } \\
\text { Ilmu Pengetahuan Alam }\end{array}$} & Biologi & $15(11 \%)$ & \multirow{6}{*}{$132(23 \%)$} \\
\hline & & Fisika & $15(11 \%)$ & \\
\hline & & Pendidikan Biologi & $12(9 \%)$ & \\
\hline & & Pendidikan Fisika & $35(27 \%)$ & \\
\hline & & Pendidikan Kimia & $12(9 \%)$ & \\
\hline & & Pendidikan Matematika & $43(33 \%)$ & \\
\hline \multirow{4}{*}{6} & \multirow{3}{*}{ Fakultas Teknik } & D3 Teknik Mesin & $34(48 \%)$ & \multirow{3}{*}{$71(21 \%)$} \\
\hline & & D3 Teknik Sipil & $15(21 \%)$ & \\
\hline & & Teknik Bangunan & $22(31 \%)$ & \\
\hline & Total & & & 580 \\
\hline
\end{tabular}




\section{HASIL}

Sebaran mahasiswa yang menjadi responden penelitian sangat bervariasi dari segi jumlah pada masing-masing program studi dan fakultas. Terdapat satu fakultas di UNJ yang tidak merespon angket, yaitu Fakultas Ilmu Sosial (FIS). Berikut ini tabel yang menunjukkan fakultas, program studi, dan jumlah mahasiswa yang menjadi responden. Secara keseluruhan, terdapat 580 mahasiswa yang menjadi responden, yang berasal dari 22 program studi dan mencakup 6 fakultas di UNJ. Responden paling banyak berasal dari program studi Pendidikan Bahasa Perancis sebanyak 44 mahasiswa, sementara yang paling sedikit berasal dari program studi Pendidikan Luar Biasa sebanyak 8 mahasiswa. Berdasarkan fakultas, responden paling banyak berasal dari Fakultas Bahasa dan Seni sebanyak 158 mahasiswa atau $27 \%$ dari total responden, sementara yang paling sedikit berasal dari Fakultas Ilmu Olahraga sebanyak 38 mahasiswa atau $7 \%$ dari total responden.

\section{Pilihan Sumber Belajar Mahasiswa pada Setiap Fakultas}

Mahasiswa UNJ, pada setiap fakultas, memiliki kecenderungan pilihan jenis sumber belajar masing-masing. Berikut ini hasil pengumpulan data terkait pilihan jenis sumber belajar mahasiswa pada setiap fakultas, yang dimulai dari Fakultas Bahasa dan Seni, Fakultas Ekonomi, Fakultas Ilmu Olahraga, Fakultas Ilmu Pendidikan, Fakultas Matematika dan Ilmu Pengetahuan Alam, serta Fakultas Teknik.

\section{Fakultas Bahasa dan Seni}

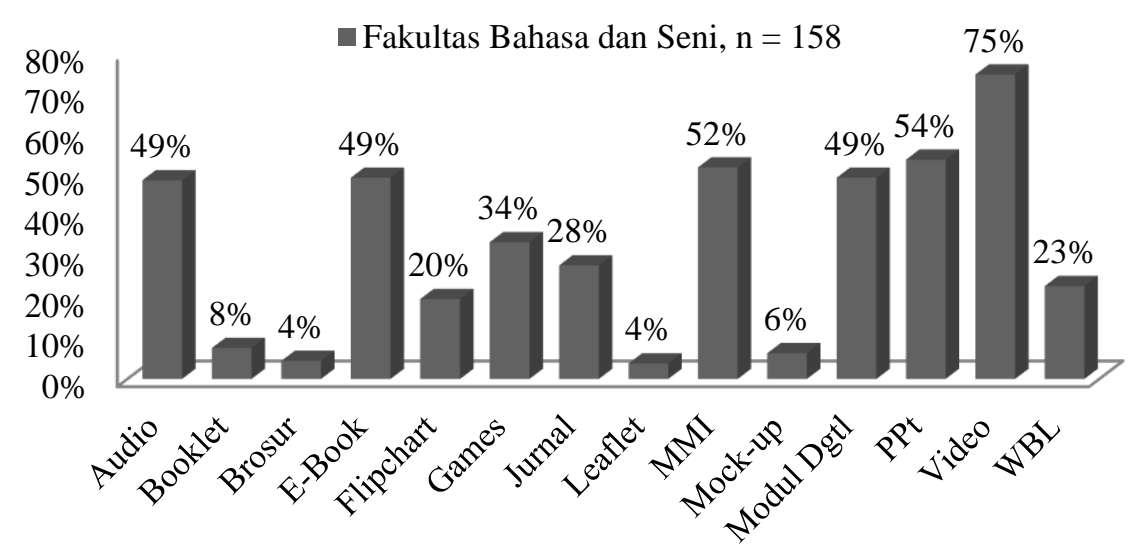

Diagram 1: Pilihan sumber belajar mahasiswa Fakultas Bahasa dan Seni

Sumber belajar yang paling banyak dipilih oleh mahasiswa Fakultas Bahasa dan Seni (FBS) UNJ adalah video, yang dipilih oleh $75 \%$ mahasiswa. Angka ini hampir dua kali lipat lebih banyak dibandingkan dengan sumber belajar games (34\%) dan jurnal (28\%), serta hampir tiga kali lipat lebih banyak dibandingkan dengan sumber belajar WBL (23\%) dan flipchart (20\%). Sumber belajar audio, e-book, dan modul digital mendapatkan angka yang sama yaitu sejumlah 49\%. PPT dan MMI merupakan sumber belajar yang paling banyak kedua dan ketiga yang dipilih oleh mahasiswa FBS UNJ mendapatkan angka masing-masing sejumlah $54 \%$ dan $52 \%$. Sedangkan 4 sumber belajar lainnya hanya dipilih oleh kurang dari $10 \%$ mahasiswa, yaitu booklet $(8 \%)$, mock-up (6\%), serta brosur dan leaflet yang keduanya mendapatkan angka $4 \%$. 


\section{Fakultas Ekonomi}

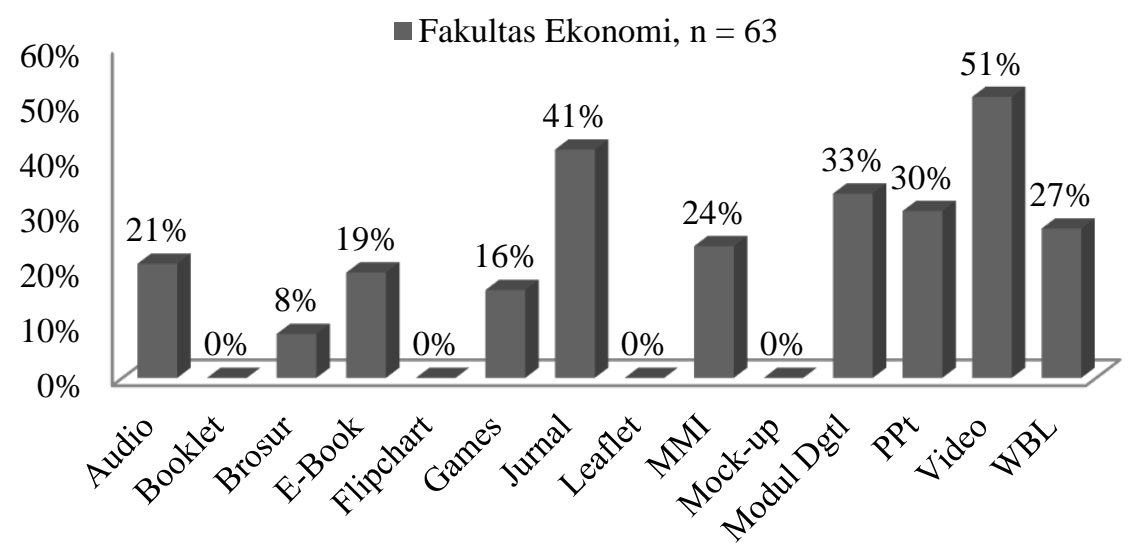

Diagram 2: Pilihan sumber belajar mahasiswa Fakultas Ekonomi

Sumber belajar yang paling banyak dipilih oleh mahasiswa Fakultas Ekonomi (FE) UNJ adalah video yang dipilih oleh $51 \%$ mahasiswa. Angka ini disusul sumber belajar jurnal sebagai pilihan terbanyak kedua yang hanya selisih $10 \%$ lebih sedikit dibanding dengan sumber belajar video. Modul digital, PPt, dan WBL berada di bawah sumber belajar jurnal yang ketiganya masing-masing hanya selisih $3 \%$ yaitu sejumlah $33 \%, 30 \%$, dan $27 \%$.
MMI, audio, dan e-book mendapatkan angka hampir sama yang masing-masing sejumlah $23 \%$, $21 \%$, dan 19\%. Games hanya dipilih oleh sejumlah $16 \%$ mahasiswa, meski angka ini lebih banyak dua kali lipat dibandingkan dengan sumber belajar brosur yang dipilih oleh $8 \%$ mahasiswa. Sedangkan 4 sumber belajar lainnya, yaitu booklet, flipchart, leaflet, dan mock-up, tidak dipilih oleh $1 \%$ responden sekalipun.

\section{Fakultas Ilmu Olahraga}

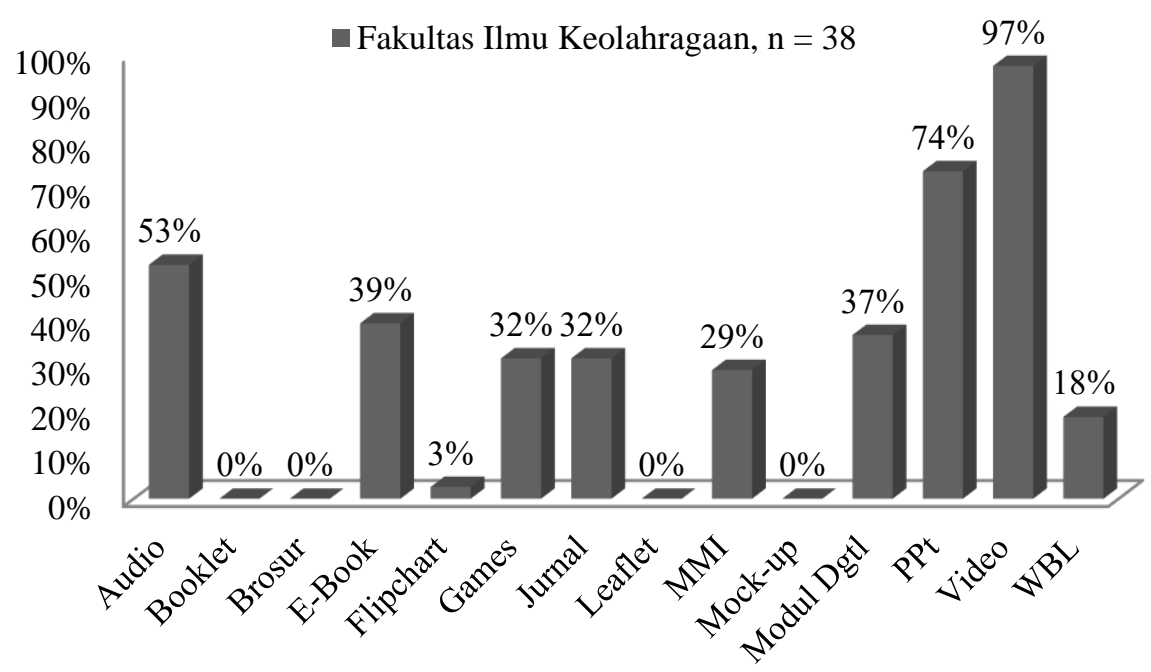

Diagram 3: Pilihan sumber belajar mahasiswa Fakultas Ilmu Olahraga 
Sumber belajar yang paling banyak dipilih oleh mahasiswa Fakultas Ilmu Olahraga (FIO) UNJ adalah video yang dipilih oleh hampir 100\% mahasiswa. Angka ini hampir 2 kali lipat dibandingkan dengan sumber belajar audio (53\%) yang merupakan sumber belajar paling banyak dipilih ketiga oleh mahasiswa. Sementara sumber belajar yang paling banyak dipilih kedua adalah PPt dengan angka yang masih cukup tinggi yaitu di atas $70 \%$.
Sumber belajar lain hanya mendapatkan angka dibawah $50 \%$ yang terdiri dari e-book (39\%), modul digital (37\%), games dan jurnal (32\%), MMI (29\%), dan WBL (18\%). Sedangkan sumber belajar flipchart, hanya 5\% mahasiswa yang memilihnya. Pada sisi lain, booklet, brosur, leaflet, dan mock-up sama sekali tidak ada yang memilihnya.

\section{Fakultas Ilmu Pendidikan}

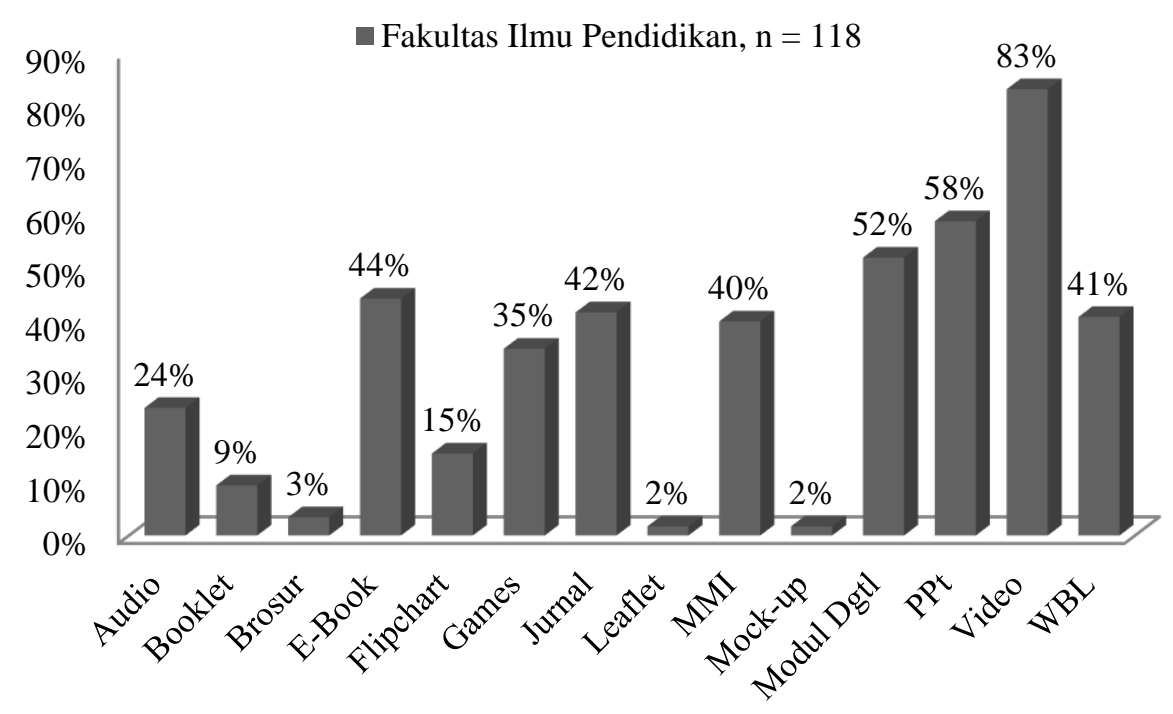

Diagram 4: Pilihan sumber belajar mahasiswa Fakultas Ilmu Pendidikan

Sumber belajar yang paling banyak dipilih oleh mahasiswa Fakultas Ilmu Pendidikan (FIP) UNJ adalah video yang dipilih oleh $80 \%$ mahasiswa. Sumber belajar PPt dan modul digital menempati urutan terbanyak kedua dan ketiga yang keduanya masing-masing dipilih oleh sejumlah 58\% dan 52\% mahasiswa.
E-Book, jurnal, WBL, dan MMI mendapatkan angka yang hampir sama yaitu $44 \%$, $42 \%, 41 \%$, dan $40 \%$. Games dipilih oleh sejumlah $35 \%$ responden, yang mana angka tersebut dua kali lipat lebih banyak dibanding audio yang hanya mendapatkan angka $24 \%$. Sumber belajar lainnya, yaitu booklet, brosur, leaflet dan mockup, hanya dipilih oleh $10 \%$ mahasiswa. 


\section{Fakultas Matematika dan Ilmu Pengetahuan Alam}

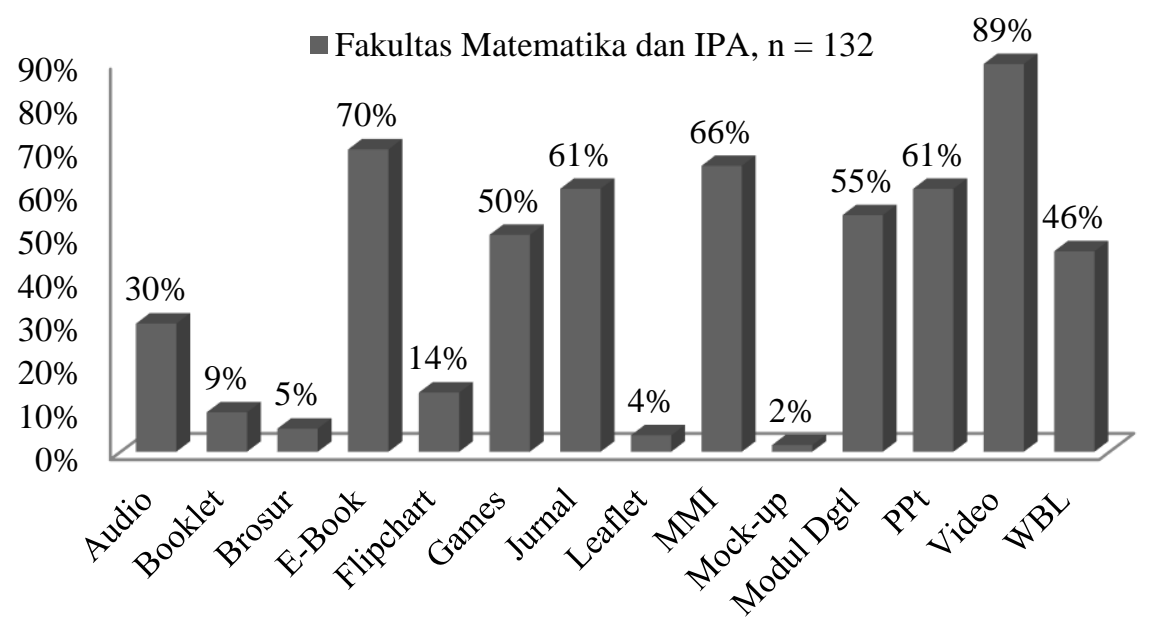

Diagram 5: Pilihan sumber belajar mahasiswa Fakultas Matematika dan IPA

Sumber belajar yang paling banyak dipilih oleh mahasiswa Fakultas Matematika dan Ilmu Pendidikan Alam (FMIPA) UNJ adalah video yang dipilih oleh hampir $90 \%$ mahasiswa. E-book dan MMI menjadi sumber belajar yang paling banyak dipilih kedua dan ketiga dengan masingmasing dipilih oleh sejumlah $70 \%$ dan $66 \%$ mahasiswa. Sumber belajar jurnal dan $\mathrm{PPt}$ mendapatkan angka yang sama yaitu sejumlah $61 \%$.
Angka keduanya ini dua kali lipat lebih banyak dibandingkan dengan sumber belajar audio (30\%), dan empat kali lipat lebih banyak dibandingkan dengan sumber belajar flipchart (15\%). Modul digital, games, dan WBL memiliki selisih angka yang tidak jauh berbeda, yaitu masing-masing dipilih oleh sejumlah 55\%, 50\%, dan $46 \%$ mahasiswa. Sedangkang sumber belajar lainnya, yaitu booklet, brosur, leaflet dan mockup, hanya dipilih oleh kurang dari $10 \%$ mahasiswa.

\section{Fakultas Teknik}

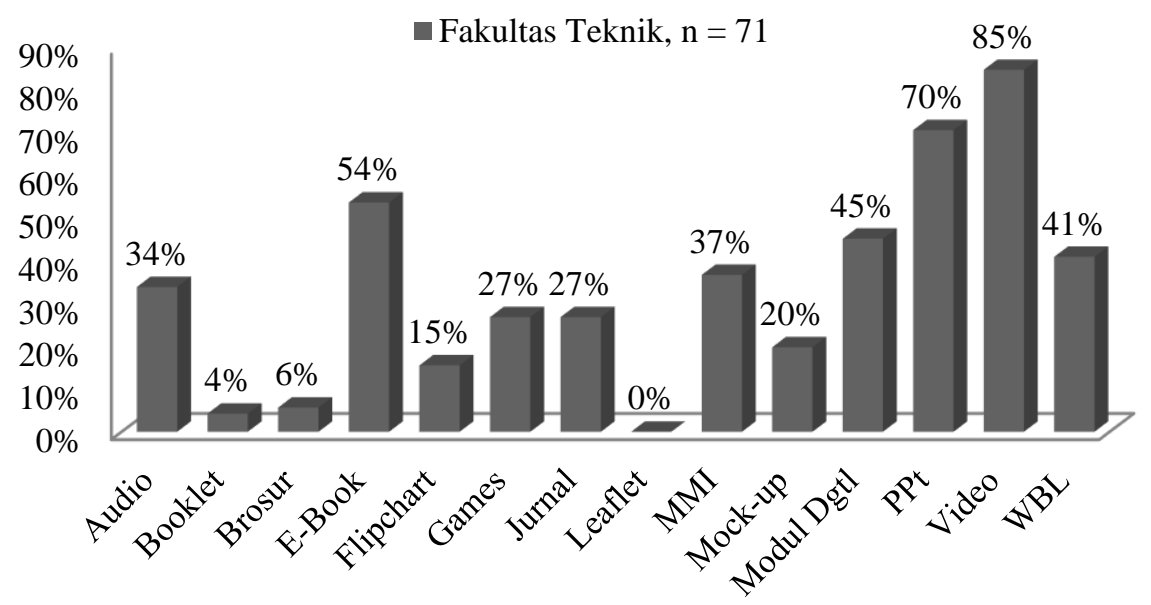

Diagram 6: Pilihan sumber belajar mahasiswa Fakultas Teknik 
Sumber belajar yang paling banyak dipilih oleh mahasiswa Fakultas Teknik (FT) UNJ adalah video yang dipilih oleh sejumlah $85 \%$ mahasiswa. Angka ini disusul oleh sumber belajar PPt yang hanya selisih $15 \%$ lebih sedikit. Namun pada sumber belajar yang paling banyak dipilih ketiga yaitu e-book, hanya dipilih oleh $54 \%$ mahasiswa, angka ini memiliki selisih yang cukup banyak dibandingkan dengan sumber belajar video. Modul digital, WBL, MMI, dan audio mendapatkan angka yang hampir sama yang masing-masing dipilih oleh sejumlah $45 \%, 41 \%$, $37 \%$, dan 34\% mahasiswa. Sumber belajar games dan jurnal mendapatkan angka yang sama yaitu sejumlah $27 \%$. Sementara sumber belajar moack- up mendapatkan angka sejumlah 20\%, dimana angka ini hanya $5 \%$ lebih tinggi dibanding dengan sumber belajar flipchart. Sedangkan mahasiswa yang memilih brosur dan booklet hanya dibawah $7 \%$, dan bahkan sumber belajar leaflet tidak dipilih oleh satu responden sekalipun.

\section{Pilihan Sumber Belajar Mahasiswa pada Tingkat Universitas}

Data pada tingkat universitas merupakan gabungan dari seluruh fakultas yang mahasiswanya berpartisipasi sebagai responden. Berikut ini diagram kebutuhan sumber belajar mahasiswa secara keseluruhan pada tingkat universitas.

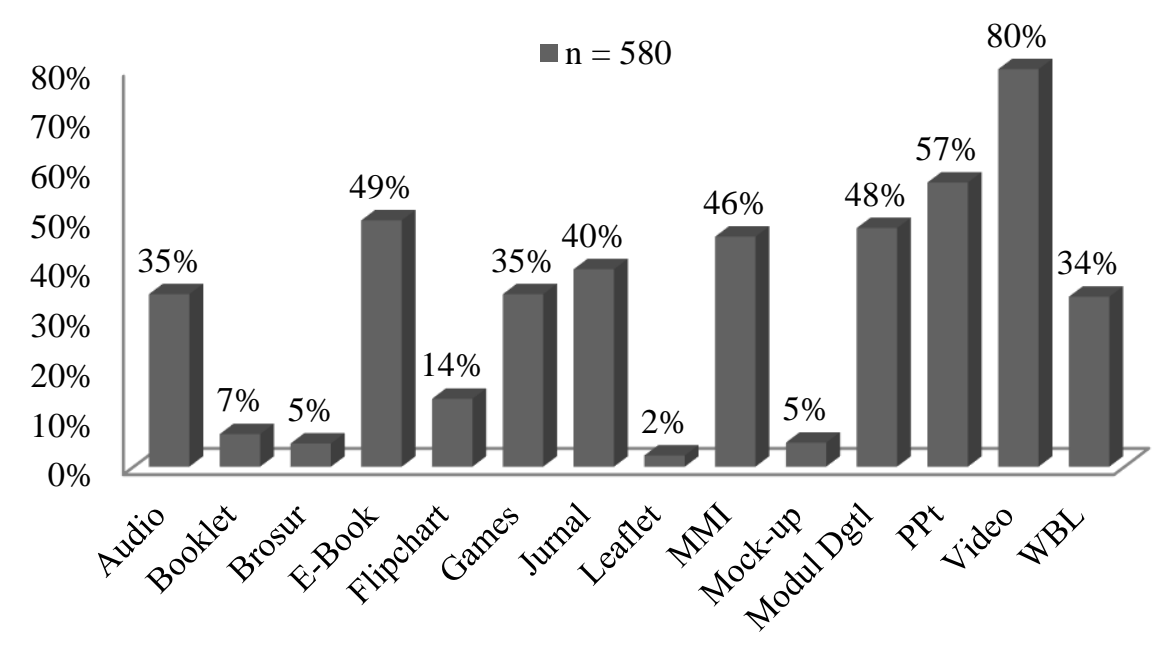

Diagram 7: Pilihan sumber belajar mahasiswa secara keseluruhan

Sumber belajar yang paling banyak dipilih oleh mahasiswa UNJ adalah video yang dipilih oleh sejumlah 80\% mahasiswa. Angka tersebut lebih banyak dua kali lipat dibanding dengan sumber belajar berupa Jurnal yang dipilih oleh sejumlah $40 \%$ mahasiswa. Sementara sumber belajar yang paling banyak dipilih kedua dan ketiga adalah PPt dan e-book yang masingmasing dipilih oleh sejumlah $57 \%$ dan $49 \%$ mahasiswa. Angka pilihan sumber belajar pada e- book (49\%) hanya $1 \%$ lebih tinggi dibanding dengan angka pada pilihan sumber belajar modul digital (48\%). Kemudian, angka pada pilihan sumber belajar modul digital hanya $2 \%$ lebih tinggi dibanding dengan angka pada pilihan sumber belajar MMI (46\%). Audio dan games mendapatkan angka yang sama yaitu sejumlah $35 \%$. Sumber belajar WBL mendapatkan angka yang hanya $1 \%$ lebih rendah dibanding dengan dua sumber belajar sebelumnya, yaitu sejumlah 
$34 \%$. Sementara flipchart hanya dipilih oleh $15 \%$ mahasiswa. Sedangkan sumber belajar lainnnya, yaitu booklet, brosur, mock-up, dan leaflet, hanya dipilih oleh kurang dari 10\% mahasiswa.

\section{PEMBAHASAN}

Meskipun

mahasiswa memiliki kecenderungan pilihan jenis sumber belajar masing-masing pada setiap fakultas, namun terdapat beberapa jenis sumber belajar yang cenderung selalu dipilih oleh mayoritas mahasiswa. Berdasarkan pada kecenderungan pilihan jenis sumber belajar, pada setiap fakultas dan secara keseluruhan pada tingkat universitas, maka dapat diketahui kebutuhan sumber belajar mahasiswa yang mendukung pembelajaran berbasis TIK di perguruan tinggi.

\section{Kebutuhan Sumber Belajar Mahasiswa pada Setiap Fakultas}

Pada setiap fakultas, video merupakan sumber belajar yang selalu paling banyak dipilih oleh mahasiswa. Terutama oleh mahasiswa Fakultas Ilmu Olahraga yang hampir 100\% memilih video sebagai sumber belajar. Pada fakultas yang lain, kecuali Fakultas Ekonomi (51\%), video selalu dipilih oleh lebih dari $70 \%$ mahasiswa. Hal ini menunjukkan bahwa video menjadi sumber belajar yang paling dibutuhkan pada setiap fakultas.

Video pembelajaran atau instructional videos merupakan sumber belajar yang banyak digunakan dalam pembelajaran digital dan online. Penggunaannya sangat efektif untuk demonstrasi berbagai keterampilan dan membawa hasil positif terhadap peningkatan hasil belajar seni ( $\mathrm{Yu}$, Jiang, \& Hauptmann, 2014), praktek kesehatan
(Gadbury-Amyot, Purk, Williams, \& Van Ness, 2014), berbicara bahasa inggris (Burt, 1999) dan olahraga (Zhang \& Chawla, 2012; Cooper \& Higgins, 2015). Sehingga wajar apabila video pembelajaran ini dipilih oleh semua mahasiswa dari Fakultas Ilmu Olahraga yang menjadi responden penelitian.

Selain video, perlu dilihat secara mendetail terhadap kencenderungan sumber belajar lainnya pada masing-masing fakultas. Mengingat bahwa terdapat perbedaan yang cukup signifikan pada pilihan sumber belajar lainnya pada setiap fakultas. Seperti terlihat pada sumber belajar audio yang cukup banyak dipilih oleh mahasiswa Fakultas Bahasa dan Seni (49\%) dan Fakultas Ilmu Olahraga (53\%), sedangkan pada fakultas yang lain hanya dipilih oleh kurang dari $35 \%$ mahasiswa. Audio memang merupakan sumber belajar yang sangat populer sejak sebelum abad 21 , popularitasnya terutama untuk pembelajaran bahasa dalam bentuk misalnya audio tutorial (Kulik, Kulik, \& Cohen, 1979). Sumber belajar audio saat ini juga masih sangat populer pada pembelajaran bahasa dalam lingkungan belajar online (Olesova, Richardson, Weasenforth, \& Meloni, 2011).

Kecenderungan sebaliknya terjadi pada sumber belajar WBL. Pada Fakultas Bahasa dan Seni dan Fakultas Ilmu Olahraga, sumber belajar WBL hanya dipilih oleh kurang dari $25 \%$ mahasiswa. Pada Fakultas Ekonomi sumber belajar WBL hanya dipilih oleh $27 \%$ mahasiswa. Sedangkan pada tiga fakultas yang lainnya, sumber belajar WBL dipilih oleh lebih dari $40 \%$ mahasiswa. Perkembangan teknologi Internet dan penetrasi penggunanya yang terus meningkat, membuat WBL mulai banyak dikembangkan dan 
digunakan sebagai sumber belajar. WBL dapat digunakan sebagai suplemen pembelajaran tatap muka, bantuan dalam pembelajaran campuran, atau sebagai sumber belajar utama dalam pembelajaran yang sepenuhnya dilakukan dalam jaringan (Davidson-Shivers, Rasmussen, \& Lowenthal, 2018).

Pada akhirnya dapat dimaknai bahwa, meskipun video menjadi sumber belajar yang paling banyak dipilih oleh mahasiswa pada semua fakultas, sumber belajar lainnya memiliki proporsi pilihan yang berbeda-beda pada masingmasing fakultas. Perbedaan pilihan yang cukup signifikan pada sumber belajar lainnya, perlu menjadi perhatian apabila ingin mengembangkan sumber belajar pada setiap fakultas. Jika perbedaan itu tidak diperhatikan dapat mengakibatkan pengembangan sumber belajar yang kurang tepat pada masing-masing fakultas.

\section{Kebutuhan Sumber Belajar Mahasiswa pada Tingkat Universitas}

Secara keseluruhan pada tingkat universitas, video menjadi sumber belajar yang paling dibutuhkan oleh mahasiswa, yang dipilih oleh $80 \%$ mahasiswa. PPt, e-book, modul digital, dan MMI menjadi sumber belajar selanjutnya yang paling dibutuhkan oleh mahasiswa, yang keempat sumber belajar tersebut dipilih oleh lebih dari 45\% mahasiswa. Menyusul berikutnya yaitu jurnal, audio, games, dan WBL yang dibutuhkan oleh sepertiga lebih mahasiswa. Sedangkan sumber belajar lainnya, yaitu booklet, brosur, flipchart, leaflet, dan mock-up, sepertinya tidak terlalu dibutuhkan oleh mahasiswa.

Sumber belajar non-digital mulai tidak terlalu dibutuhkan oleh mahasiswa dalam konteks pembelajaran berbasis TIK yang semuanya sudah serba digital. Pada pembelajaran berbasis TIK, teknologi harus digunakan semaksimal mungkin untuk mengeksplorasi berbagai sumber belajar dalam format digital. Contoh yang baik dapat melihat pada Walton, Childs, \& Blenkinsopp (2005) yang memanfaatkan mobile technologies untuk membuka akses seluas-luasnya terhadap sumber belajar. Relasi antara jenis sumber belajar dengan ketersedian teknologi yang dapat digunakan untuk mengakses sumber belajar harus benar-benar diperhatikan kesesuaiannya. Sumber belajar digital dalam pembelajaran berbasis TIK bisa jadi sangat baik dan relevan, namun sumber belajar non-digital bukan berarti tidak bisa digunakan untuk memfasilitasi dan meningkatkan hasil belajar dan pembelajaran di perguruan tininggi.

Melihat kebutuhan sumber belajar pada tingkat universitas, dapat dijadikan bahan pertimbangan apabila ingin mengembangkan sumber belajar yang akan digunakan oleh mahasiswa secara keseluruhan pada tingkat universitas. Seperti dalam pengembangan sumber belajar pada mata kuliah dasar umum (MKDU) yang mana mata kuliah ini diikuti oleh semua mahasiswa. Namun, pengembangan sumber belajar pada mata kuliah yang diajarkan pada fakultas tertentu, sebaiknya melihat kebutuhan sumber belajar pada setiap fakultas.

Secara nyata, TIK dapat meningkatkan keterlibatan aktif (engagement) dalam pembelajaran (Kearsley \& Shneiderman, 1998) dan pengelolaan sumber belajar yang baik dapat meningkatkan hasil belajar (Yara \& Otieno, 2010; Namunga \& Wanjala, 2017). Maka, sumber belajar yang sesuai dengan kebutuhan mahasiswa 
dan perkembangan ilmu pengetahuan, teknologi, dan seni perlu dikembangkan oleh perguruan tinggi guna memfasilitasi dan meningkatkan hasil belajar dan pembelajaran berbasis TIK secara maksimal. Melalui pengembangan sumber belajar pada perguruan tinggi yang sesuai dengan kebutuhan dan berbagai perkembangan, diharapkan mahasiswa dapat terfasilitasi dengan baik terkait sumber belajar, semakin aktif keterlibatannya dalam proses belajar dan pembelajaran, serta meningkat prestasi belajarnya.

Perlu diingat bahwa pengembangan sumber belajar tidak berarti selalu dan harus dilakukan sendiri dari awal. Pengembangannya dapat dilakukan berdasarkan tiga cara berikut; 1) membuat sendiri sumber belajar; 2) memodifikasi atau kompilasi dari berbagai sumber belajar yang telah ada; 3) mengadaptasi yaitu menggunakan sebagaian atau secara utuh sumber belajar yang telah ada (Sitepu, 2004: 6). Selain membuat sendiri dari awal, sumber belajar dapat dikembangkan dengan memodifikasi, mengkompilasi, dan mengadaptasi sebagaian atau secara utuh sumber belajar yang telah ada.

Pengambilan keputusan terkait cara yang akan dipilih disesuaikan dengan kebutuhan dan sumber daya masing-masing. Kebutuhan pengembangan sumber belajar sangat tergantung dengan masalah kontekstual terkait sumber belajar pada masing-masing institusi pendidikan. Sumber daya pengembangan sumber belajar juga memiliki kuantitas dan kualitas yang berbedabeda pada masing-masing institusi pendidikan. Tidak semua institusi pendidikan memiliki sumber daya baik dalam bentuk manusia maupun non-manusia yang memadai untuk melakukan pengembangan sumber belajar.

Lebih jauh, pengembangan sumber belajar harus dilakukan dengan terstruktur, sistemik, dan sistematis. Perlu adanya suatu lembaga khusus yang memiliki tugas pokok dan fungsi melakukan pengembangan sumber belajar. Lembaga yang dimaksud adalah Pusat Sumber Belajar (PSB). Meski eksistensi PSB di perguruan tinggi saat ini cenderung menurun yang dikarenakan lemahnya landasan formal, kebijakan, dan dan sumber dana (Rahmadi, 2017b; 141), keberadaannya masih tetap dibutuhkan, dengan catatan fungsi PSB sendiri harus dikembangan sesuai dengan masalah dan kebutuhan terbaru di perguruan tinggi.

Fungsi PSB masa depan di perguruan tinggi harus dikembangkan pada; 1) pengembangan sistem pembelajaran berbasis teknologi; 2) pelayanan susmber belajar kepada mahasiswa dan dosen; 3) penyelenggaraan berbagai pelatihan atau kursus yang dapat diikuti dengan fleksibel; 4) administrasi PBS secara online (Rahmadi, 2017a; 95). Pengambangan fungsi ini diharapkan dapat meningkatkan eksistensi PSB di perguruan tinggi dan meningkatkan peran yang maksimal untuk dapat mengembangkan sumber belajar mahasiswa dan dosen yang mendukung pembelajaran berbasis TIK.

Perkembangan ilmu pengetahuan, teknologi, dan seni tidak dapat dielakkan karena merupakan suatu keniscayaan. Pengembangan sumber belajar mahasiswa yang mendukung pembelajaran berbasis TIK juga merupakan suatu keniscayaan. Lebih lanjut, pengembangan sumber belajar yang akan berfungsi melakukan pengembangan dan pengelolaan berbagai sumber belajar juga merupakan suatu keniscayaan. Maka, inisiatif 
berbagai pengembangan dalam bidang teknologi pendidikan perlu untuk terus dilakukan secara berkelanjutan supaya tetap sesuai dengan perkembangan ilmu pengetahuan, teknologi, dan seni.

Disiplin ilmu teknologi pendidikan merupakan studi dan praktek etis dalam menciptakan (creating), menggunakan (using), serta mengelola (managing) proses dan sumber daya teknologi tepat guna untuk memfasilitasi belajar dan meningkatkan kinerja pemelajar (Januszewski dan Molenda, 2008: 213). Maka menciptakan, menggunakan, dan mengelola sumber belajar mahasiswa yang mendukung pembelajaran berbasis TIK merupakan suatu studi dan praktek etis dalam memfasilitasi belajar dan meningkatkan kinerja pemelajar. Pemenuhan kebutuhan sumber belajar mahasiswa sesuai dengan prioritas kebutuhan yang ada merupakan upaya nyata untuk memfasilitasi belajar mahasiswa dengan baik dan meningkatkan hasil belajar mahasiswa secara signifikan.

Para teknolog pendidikan diharapkan dapat meneruskan studi dan praktek etis dalam pengembangan, penggunaan, dan pengelolaan sumber belajar. Studi ini dapat dijadikan sebagai pijakan dasar untuk melakukan studi lebih lanjut yang serupa pada lingkungan berbeda untuk dapat dilakukan perbanding terhadap hasil yang ditemukan. Sehingga, pada akhirnya, antara satu studi dengan studi yang lain dapat saling melengkapi dan kemudian mendorong studi lebih lanjut berikutnya.

Pengembangan sumber belajar di perguruan tinggi hendaknya diprioritaskan dalam pengembangan video pembelajaran. Apabila ingin mengembangkan sumber belajar pada masing-masing

fakultas

harus mempertimbangkan kecenderungan kebutuhan sumber belajar mahasiswa pada setiap fakultas. Pada pembelajaran berbasis TIK, sumber belajar berupa booklet, brosur, flipchart, leaflet, mock-up dan sumber belajar tradisional lainnya hendaknya dibatasi pengembangannya.

Penelitian analisis sumber belajar yang dibutuhkan oleh mahasiswa dalam pembelajaran berbasis TIK perlu dilakukan pada perguruan tinggi lain guna mendapatkan perbandingan hasil. Kebutuhan sumber belajar perlu dianalisis lebih mendalam hingga melihat bukan hanya pada fakultas yang berbeda, namun juga pada gaya belajar mahasiswa yang berbeda. Selain itu, analisis sumber belajar yang dibutuhkan dalam perkuliahan online juga dapat dilakukan untuk penelitian selanjutnya.

Pengembangan sumber belajar pada suatu institusi pendidikan harus dilakukan dengan tepat. Supaya pengembangan sumber belajar pada perguruan tinggi dapat dilakukan dengan tepat, dapat memperhatikan kesimpulan dan mempertimbangkan saran penelitian ini. Selain itu, juga terdapat rekomendasi penelitian selanjutnya, yang dapat dijadikan acuan para peneliti pada bidang teknologi pendidikan untuk dapat meneliti secara berkelanjutan terkait dengan sumber belajar.

\section{KESIMPULAN}

Sumber belajar berupa video merupakan sumber belajar yang paling dibutuhkan oleh mahasiswa guna mendukung pembelajaran berbasis TIK di perguruan tinggi. Namun, selain video, pada setiap fakultas memiliki perbedaan kecenderungan kebutuhan sumber belajar lainnya. 
Sumber belajar berupa booklet, brosur, flipchart, leaflet, dan mock-up, tidak terlalu dibutuhkan oleh mahasiswa dalam konteks pembelajaran berbasis TIK. Analisis terhadap kebutuhan sumber belajar pada perguruan tinggi harus dilakukan secara berkala dan berkelanjutan mengingat bahwa ilmu pengetahuan, teknologi, dan seni terus berkembang dengan cepat.

\section{DAFTAR PUSTAKA}

Burt, M. (1999). Using Videos with Adult English Language Learners. ERIC Digest.

Cooper, D., \& Higgins, S. (2015). The effectiveness of online instructional videos in the acquisition and demonstration of cognitive, affective and psychomotor rehabilitation skills: The effectiveness of online instructional videos. British Journal of Educational Technology, 46(4), 768-779. https://doi.org/10.1111/bjet.12166

Davidson-Shivers, G. V., Rasmussen, K. L., \& Lowenthal, P. R. (2018). Overview of Online Instruction and Learning Environments and Communities. Dalam G. V. Davidson-Shivers, K. L. Rasmussen, \& P. R. Lowenthal, WebBased Learning (hlm. 3-41). Cham: Springer International Publishing. https://doi.org/10.1007/978-3-31967840-5_1

Framework for 21st Century Learning - P21. (t.t.). Diambil 24 Juli 2018, dari http://www.p21.org/our-work/p21-framework
Gadbury-Amyot, C. C., Purk, J. H., Williams, B. J., \& Van Ness, C. J. (2014). Using tablet technology and instructional videos to enhance preclinical dental laboratory learning. Journal of dental education, 78(2), 250-258.

Irwin, C., Ball, L., Desbrow, B., \& Leveritt, M. (2012). Students' perceptions of using Facebook as an interactive learning resource at university. Australasian Journal of Educational Technology, 28(7). https://doi.org/10.14742/ajet.798

Island, P. E. (2008). Evaluation and Selection of Learning Resources: A Guide. Charottetown, Canada: http://www. gov. pe. ca/educ.

Januszewski, A, \& Molenda, M. (2008). Educational Technology: A Definition with Commentary. New York: Lawrence Erlbaum Associates.

Januszewski, A. (2001). Educational Technology: The Development of a Concept. Colorado: Libraries Unlimited.

Kanah. (2014). "Analisis Kebutuhan Pengembangan Bahan Ajar Bahasa Jepang pada Program Studi D III Usaha Perjalanan Wisata dan Perhotelan Jurusan Pariwisata Politeknik Negeri Bali”. SOSHUM: Jurnal Sosial dan Humaniora. Vol. 4, No. 3, h. 197-205.

Kearsley, G., \& Shneiderman, B. (1998). Engagement Theory: A Framework for Technology-Based Teaching and 
Learning. Educational Technology, $38(5), 20-23$.

Kereluik, K., Mishra, P., Fahnoe, C., \& Terry, L. (2013). What knowledge is of most worth: Teacher knowledge for 21st century learning. Journal of Digital Learning in Teacher Education, 29(4), 127-140.

Khabibah, E. N., Wijayanti, F. N., Choirina, Y., \& Sajidan. (2015). “Analisis Kebutuhan Pengembangan Perangkat Pembelajaran Ditinjau dari Pemenuhan Standar Pendidik dan Ketuntasan Belajar Biologi SMA". Prosiding Seminar Nasional Pendidikan Sains. H. 641-647.

Kulik, J. A., Kulik, C.-L. C., \& Cohen, P. A. (1979). Research on Audio-Tutorial Instruction: A Meta-Analysis of Comparative Studies. Research in Higher Education, 11(4), 321-341.

Liu, Y. (2010). Social Media Tools as a Learning Resource. Journal of Educational Technology Development and Exchange, 3(1). https://doi.org/C., \& Corbett. (1997). “Computer-mediated communication as a learning resource". Journal of Computer Assisted Learning. Vol. 13, h. 219-227.

McGreal, R. (2004). Learning objects: A practical de fi nition. International Journal of Instructional Technology and Distance Learning, 1 (9), 21-32.

Namunga, N. W., \& Wanjala, W. B. (2017). Assessment Of The Effect Of Provision
And Management Of Resources On Teaching And Learning In Secondary Schools In Bungoma County, Kenya, $4(2), 9$.

Nurhidayah, F., Zubaidah, S., \& Kuswantoro, H. (2016). “Analisis Kebutuhan Worksheet untuk Pembelajaran Berbasis Masalah di SMKN 2 Batu". Jurnal Pendidikan: Teori, Penelitian, dan Pengembangan. Vol. 1, No. 7, h. 1224-1228.

Priyantoro, H., Suparman, \& Rizki, A. (2017). “Analisis Kebutuhan terhadap Bahan Ajar Matematika Siswa sesuai Model Pembelajaran STAD". The 5 URECOL Proceeding. H. 926-930.

Rahmadi, I. F. (2017a). "Mengembangkan Pusat Sumber Belajar di Perguruan Tinggi Berdasarkan Masalah dan Kebutuhan Terbaru". Jurnal Perspektif Ilmu Pendidikan. Vol. 31, No. 2, h. 90-96.

Rahmadi, I. F. (2017b). "Mengembangkan Pusat Sumber Belajar di Perguruan Tinggi Berdasarkan Masalah dan Kebutuhan Terbaru". Jurnal Perspektif Ilmu Pendidikan. Vol. 31, No. 2, h. 90-96.

Recker, M. M, Dorward, D, \& Nelson, L. M. (2004). Discovery and Use of Online Learning Resources: Case Study Findings. Journal of Educational Technology \& Society, 7(2), 93-104.

Republik Indonesia. (2003). Undang-Undang Nomor 20 Tahun 2003 tentang Sistem Pendidikan Nasional. Jakarta: Sekretariat Negara Republik Indonesia. 
Republik Indonesia. (2012). Undang-undang Nomor 12 Tahun 2012 tentang Pendidikan Tinggi. Jakarta: Sekretariat Negara Republik Indonesia.

Sari, R. T. \& Jusar, I. R. (2017). "Analisis Kebutuhan Modul Pembelajaran IPA Berorientasi Pendidikan Karakter Melalui Pendekatan Quantum Learning di Sekolah Dasar". BIOEDUKASI: Jurnal Pendidikan Biologi. Vol. 8, No. 1, h. 26-32.

Sitepu, B. P. (2004). Pengembangan Bahan Ajar. Jakarta: Lembaga Akta Mengejar Universitas Negeri Jakarta.

Sitepu, B. P. (2014). Pengembangan Sumber Belajar. Jakarta: Rajawali Pers.

Seels, Barbara B., dan Rita C. Richey. Teknologi Pembelajaran: Definisi dan Kawasannya, terjemahan Dewi S. Prawiradilaga, Raphael Rahardjo, dan Yusufhadi Miarso. Jakarta: Universitas Negeri Jakarta, 1994.

Walton, G., Childs, S., \& Blenkinsopp, E. (2005). Using mobile technologies to give health students access to learning resources in the UK community setting.
Health Information \& Libraries Journal, 22, 51-65.

Wiley, D. A., \& Agency for Instructional Technology (Ed.). (2002). The instructional use of learning objects (1st ed). Bloomington, Ind: Agency for Instructional Technology: Association for Educational Communications \& Technology.

Yara, P. O., \& Otieno, K. O. (2010). Teaching/learning resources and academic performance in mathematics in secondary schools in Bondo District of Kenya. Asian Social Science, 6(12), 126.

Yu, S.-I., Jiang, L., \& Hauptmann, A. (2014). Instructional Videos for Unsupervised Harvesting and Learning of Action Examples (hlm. 825-828). ACM Press. https://doi.org/10.1145/2647868.26549 97.

Zhang, N., \& Chawla, S. (2012). Effect of implementing instructional videos in a physical examination course: an alternative paradigm for chiropractic physical examination teaching. Journal of Chiropractic Education, 26(1), 4046. 